\title{
ECONOMICS OF A HIGH PERFORMANCE SOLAR DISTILLED WATER
} PLANT

\author{
Pankaj K Srivastava ${ }^{1}$, Abhay Agrawal ${ }^{2}$ \\ ${ }^{1}$ Associate Professor, ${ }^{2}$ Assistant Professor, Mechanical Engineering Department, Rewa Engg College Rewa, M.P, India
}

\begin{abstract}
In this paper, economic analysis of a high performance solar energy operated distilled water plant is presented. The monthly and the annual productivity of the high performance plant is compared with that of a conventional basin type solar still of equal size and material. The cost of the distilled water produced is determined by uniform cost analysis method. The analysis revealed that the production cost of the distilled water produced per litre by the high performance plant is Rs.5.07, whereas that for the conventional still is Rs.7.90 when the market cost is Rs.20.00. The high performance solar distilled water plant can be a very economical, cost effective, minimum maintenance and the zero energy cost option. Moreover, there is no pollution involved.
\end{abstract}

Keywords: Distilled water, solar still, porous absorber, economic analysis and high performance.

\section{INTRODUCTION}

In this modern world of industrialization and motorization, the requirement of pure water has also increased, which may be necessary for many industrial processes. Distilled water is the purest form of water, but its production requires extensive energy which may be very expensive, thereby increasing the production cost. Solar energy is the freely and vastly available energy available on our planet, besides it is free of pollution which is the necessity of this modern era. Furthermore, the solar energy applications can easily be fabricated with the help of locally available cheap materials without much labor cost. Solar stills are also one of such applications for producing distilled water. Solar stills have the advantage of simplicity, low maintenance and capital cost but they suffer from low efficiency and productivity.

A lot of research has been conducted so far to improve the productivity of the solar still. Sodha et al. [1] investigated that the performance of a solar still improves with the reduced air gap, since due to reduced air gap, the vapor length is small and the still operates by diffusion mass transfer. A wick-basin type solar still with improved productivity was developed by Minasian and Al-Karaghouli [2]. Madani and Zaki [3] conducted an experimental study on the solar still with porous basin and found an improvement in the performance. Bassam et al. [4] experimented by placing sponge cubes on basin water and observed an increase in the productivity. Karaghouli and Alnaser [5] conducted an experimental study to compare the performance of single and double slope solar stills. Samee et al. [6] conducted a study on the design and performance of a single basin solar still. Khaled Eldalil [7] improved the performance of a solar still by using vibratory harmonic effect. The distillate output due to vibration increased to $5.81 / \mathrm{m}^{2}$ day with an average daily efficiency of about $60 \%$ whereas the nocturnal production ranged from $38 \%$ to $57 \%$. Omara et al [8] conducted an experimental study to compare the performances of the finned and corrugated stills with the conventional still under the same water depth and the water quantity. They observed that the finned and the corrugated stills performed better than the conventional still due to increased absorber surface area. Kabeel et al [9] conducted an experimental study in Kafrelsheikh, Egypt in which two types of solar distillation systems were tested. It was found that the stepped solar still gave higher distillate production than the conventional still. Around 57\% higher output was obtained in the stepped still for $5 \mathrm{~mm}$ water depth. Srivastava and Agrawal [10] carried an experimental and theoretical analysis of a basin type solar still with multiple floating porous absorbers. An increase in the distillate output by around $68 \%$ over the conventional basin type solar still was observed. An experimental study was conducted by Srivastava and Agrawal [11] on the floating absorber type solar still. They observed a highest of $74.6 \%$ distillate gain in the month of January and lowest $35.5 \%$ gain in August. In this work, an economic analysis has been conducted on a high performance solar operated distilled water plant which makes use of a low thermal inertia floating porous absorber. The performance and the production cost of the high performance plant is compared with a conventional design.

\section{CONSTRUCTION AND WORKING}

Fig. 1 shows the construction of the high performance plant, which is obtained by the simple modification of a conventional basin type solar still. The modification is achieved by floating blackened jute cloth pieces on the basin water with the help of the thermocole pieces. The edges of the jute cloth pieces are dipped in the basin water so that they remain wet due to capillary action. The floating multiple 
porous absorbers respond to the incident solar radiation at appreciably faster rate than the basin water of the conventional still. This is due to the better absorptivity and low thermal inertia of the porous absorbers, hence a significantly higher distilled water output is obtained. The basin water trapped beneath the thermocole remains at relatively much lower temperatures, thereby reducing the base heat losses resulting in higher efficiency and better performance. The evaporated water vapors get condensed at the inner surface of the glass cover, from where they slide down the cover slope and get collected into the distillate channel.

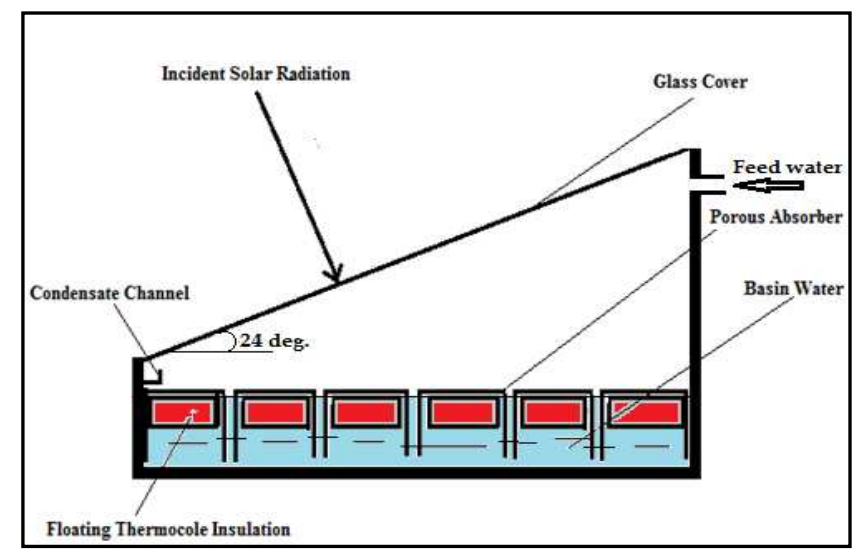

Fig-1: Construction of distilled water plant

\section{ECONOMIC ANALYSIS}

A major advantage of the solar distillation systems is their zero input energy cost due to the abundantly and freely available solar energy. Therefore, the total cost of distilled water production depends on the cost of installation of the distillation system, the cost of extra energy required other than solar energy, the maintenance cost and the cost of operation. In this section, the cost of the distilled water produced by high performance and conventional basin type is determined by uniform cost analysis method. The method can be described as follows,

Let $\mathrm{P}$ be the initial investment cost of a system, $\mathrm{r}$ be the annual rate of interest on the capital amount and $n$ be the number of useful years for which the system can perform therefore,

The Capital Recovery Factor, CRF is given as,

$$
\mathrm{CRF}=\frac{r(1+r)^{n}}{(1+r)^{n}-1}
$$

Thus, the First Annual Cost can be calculated by the relation,

$$
\text { First Annual Cost }=\mathrm{CRF} \times \mathrm{P}
$$

The Annual Salvage Value depends upon the sinking fund factor, SFF and the salvage value $\mathrm{S}$. It is given as,
Annual Salvage Value $=$ SFF $x$ S

Where, the Sinking Fund Factor, SFF is given as,

$$
\text { Sinking Fund Factor, SFF }=\frac{r}{(1+r)^{n}-1}
$$

Considering the annual maintenance cost of the system, the Annual cost of the system can be obtained as,

\section{Annual Cost $=$ First Annual Cost + Annual Maintenance Cost - Annual Salvage Value}

Assuming an annual interest rate of $12 \%$ for 10 years of useful still life and calculated values, $\mathrm{CRF}=0.1770$ and SFF $=0.0569$. A comparison is given in Table- 1 and Fig- 4 .

Table -1: Distilled water cost calculation

\begin{tabular}{|l|c|c|c|}
\hline Type of plant & $\begin{array}{c}\text { Annual } \\
\text { production, } \\
\mathrm{kg}\end{array}$ & $\begin{array}{c}\text { Annual } \\
\text { Cost } \\
\text { Rs. }\end{array}$ & $\begin{array}{c}\text { Distilled } \\
\text { water } \\
\text { Cost/litre } \\
\text { Rs. }\end{array}$ \\
\hline $\begin{array}{l}\text { High } \\
\text { Performance }\end{array}$ & 1247.8 & 6287.7 & 5.04 \\
\hline $\begin{array}{l}\text { Conventional } \\
\text { Solar Still }\end{array}$ & 792.2 & 6255.0 & 7.90 \\
\hline
\end{tabular}

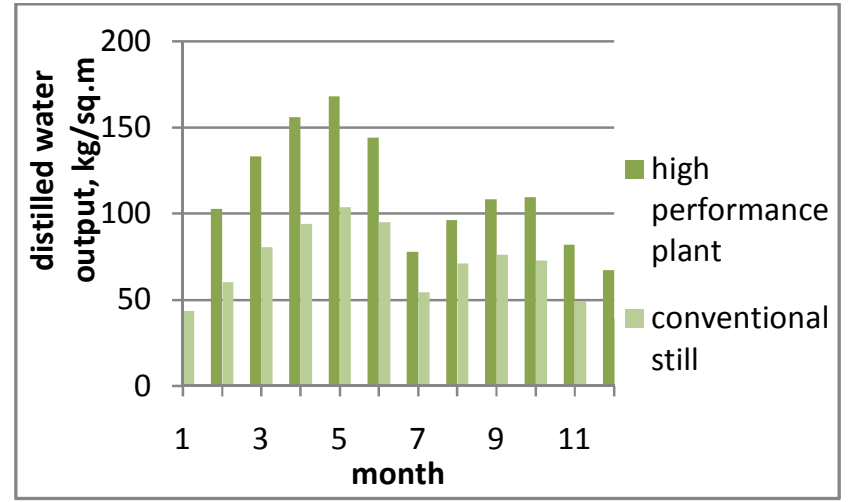

Fig -2: Monthly distilled water production

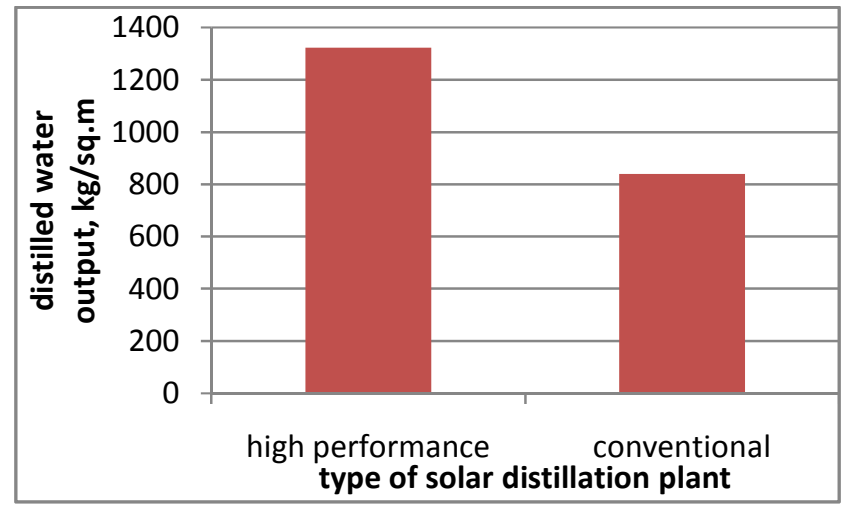

Fig -3: Annual distilled water production 


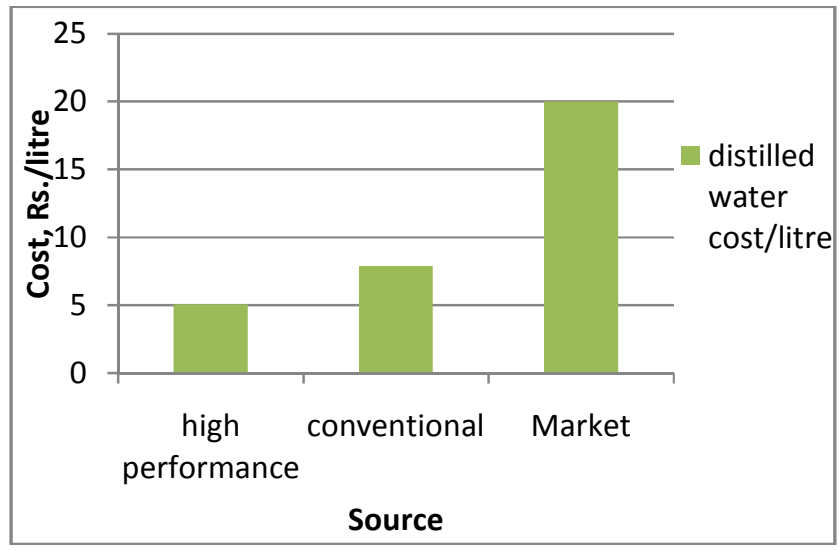

Fig -4: Distilled water cost from different sources

\section{RESULTS AND DISCUSSION}

The highlight of the high performance solar distilled water plant is its higher rate of evaporation thereby giving a higher productivity and efficiency as compared to the conventional solar still. Table-1 gives the information of the annual production and cost and the distilled water cost per litre. It can be seen that for the high performance plant the cost is much lower than that for conventional still and that obtained from the market. Fig-2 and 3 show that the monthly and annual productivity of the high performance still is appreciably higher, due to which the cost per litre of water is also minimum as shown in Fig-4.

\section{CONCLUSIONS}

The presented high performance solar distilled water plant can be a very economical, cost effective, minimum maintenance and the zero energy cost option. Moreover, there is no pollution involved.

\section{REFERENCES}

[1]. M.S. Sodha, A. Kumar, G.N. Tiwari, R.C. Tyagi, Simple multiple wick solar still: Analysis and performance, Solar Energy 26 (1981) 127-131.

[2]. A.N. Minasian, A.A. Al-Karaghouli, An improved solar still: the wick-basin type, Energy Convers. Manage. 36 (1995) 213-217.

[3]. A.A. Madani, G.M. Zaki, Yield of solar stills with porous basins, Applied Energy 52 (1995) 273-281.

[4]. A. Bassam, K. Abu -Hijleh, Hamzeh M. Rababa'h, Experimental study of solar still with sponge cubes in basin, Journal of Energy Conversion \& Management 44 (2003) 1411-1418.

[5]. A.A. Al-Karaghouli, W.E. Alnaser, Experimental comparative study of the performances of single and double basin solar-stills, Appl. Energy 77 (2004) 317-325.
[6]. M.A. Samee, U.K. Mirza, T. Majeed, N. Ahmad, Design and performance of a single basin solar still, Renew. Sustain Energy Rev. 11 (2007) 543-549.

[7]. Khaled M.S. Eldalil, Improving the performance of solar still using vibratory harmonic effect, Desalination 251 (2010) 3-11

[8]. Z.M. Omara, Mofred, H. Hamed, A.E. Kabeel, Performance of finned and corrugated absorber solar stills under Egyptian conditions, Desalination 277 (2011) 281-277.

[9]. Kabeel A.E., Khalil A., Omara Z.M., Younes M.M., Theoretical and experimental parametric study of modified stepped solar still, Desalination 289 (2012) 12-20.

[10]. Pankaj K. Srivastava, S.K. Agrawal, Experimental and theoretical analysis of single sloped basin type solar still consisting of multiple low thermal inertia floating porous absorbers, Desalination 311 (2013) 198-205.

[11]. Pankaj K. Srivastava, S.K. Agrawal, Multiple Floating Porous Absorber Type Solar Still: Annual Performance Evaluation, International Journal of Renewable Energy Technology, Article in Press.

\section{BIOGRAPHIES}

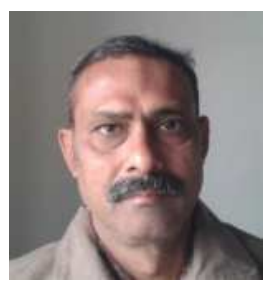

Dr. Pankaj K. Srivastava is an experienced academician and a researcher. A Gold Medalist in M.E. from MNREC Allahabad, he has been actively involved in the field of solar thermal applications, heat transfer, design and fluid mechanics. He has published a number of research papers in SCI international journals of world's reputed publishers $\mathrm{He}$ is also a registered reviewer for reputed SCI journals.

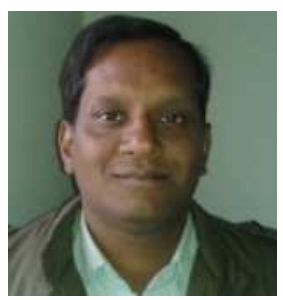

Mr. Abhay Agrawal has been related with the field of thermal applications for many years. He has done his M.E. from School of Mines, Dhanbad. 